\title{
A Case of Pneumorrhachis Associated with Spontaneous Pneumomediastinum and Subcutaneous Emphysema
}

\author{
Dong Gun Lee, Joo Geun Jung, Jun-Ook Park, and Mi Ra Kim \\ Department of Otorhinolaryngology-Head and Neck Surgery, Haeundae Paik Hospital, Inje University College of Medicine, Busan, Korea
}

\author{
피하기종과 자발성 종격동 기종에 동반된 경막외 기종 1 예 \\ 이동건 · 정주근 · 박준욱 · 김미라 \\ 인제대학교 의과대학 해운대백병원 이비인후과학교실
}

\author{
Received November 5, 2015 \\ Revised December 28, 2015 \\ Accepted January 12, 2016 \\ Address for correspondence \\ Mi Ra Kim, MD, PhD \\ Department of Otorhinolaryngology- \\ Head and Neck Surgery, \\ Haeundae Paik Hospital, \\ Inje University College of Medicine, \\ 875 Haeun-daero, Haeundae-gu, \\ Busan 48108, Korea \\ Tel $+82-51-797-2290$ \\ Fax $+82-51-797-2304$ \\ E-mail enthns@hanmail.net
}

Pneumorrhachis or epidural emphysema is an uncommon finding observed in the spinal epidural space. Pneumorrhachis could be occasionally associated with pneumomediastinum or pneumothorax or subcutaneous emphysema. Probably this results from air that leaks from the mediastinum, which traverses through the fascial planes and intervertebral neural foramina. In particular, without any causes, these conditions rarely appear simultaneously with trauma, surgery, malignancy, anesthesiological interventions, or Valsalva maneuvers. We report a case of pneumorrhachis accompanied by spontaneous pneumomediastinum and subcutaneous emphysema that was resolved after conservative treatment.

Korean J Otorhinolaryngol-Head Neck Surg 2016;59(9):684-7

Key Words Pneumomediastinum - Pneumorrhachis · Subcutaneous emphysema.
서 론 과 함께 보고하고자 한다.

경막외 기종의 정의는 척수 경막외 공간에 공기가 존재하 는 상태로 위치에 따라 두개강내와 두개강외로 구분할 수 있 다. 비교적 높은 사망률을 보인다고 알려진 두개강내의 경막 외 기종과는 달리 두개강외의 경막외 기종은 예후가 좋은 것 으로 알려져 있다.1) 두개강외 경막외 기종은 주로 외상에 의 해서 발생하며, 발생 원인에 따라서 외상성, 의인성, 자발성으 로 구분할 수 있고, 그중에서 자발성 경막외 기종은 비외상 성 또는 자발성 종격동 기종, 기흥, 또는 퇴행성 디스크 질환 에 동반해서 발생할 수 있다고 알려져 있다. ${ }^{2,3)}$ 외상이나 다 른 원인 없이 자발성 종격동 기종, 피하기종, 자발성 경막외 기종이 동시에 같이 발생하는 것은 매우 드물다. 저자들은 인후통과 경부의 전반적인 부종과 통증을 주소로 내원한 환 자에게서 시행한 영상학적 검사상 경부 피하기종, 종격동 기 종, 그리고 경막외 기종이 동반된 사례를 경험하여 문헌고찰
증 례

16세 남자 환자가 1주 전부터 발생한 인후통 증상으로 개 인병원에서 편도염 의증으로 치료받던 중 내원 2일 전부터 목 주변의 부종이 발생하여 본원에 전원되었다. 인후통은 감 소하였으나 경부의 부종과 통증은 점점 진행하는 양상이었 다. 두통, 호흡곤란, 기침, 가슴통증과 같은 다른 동반 증상 은 없었다. 과거력상 천식, 결핵, 격렬한 운동이나 경부나 흥 부 주변의 외상력, 기관지 흡입제의 사용, 최근의 수술력은 없었다. 신체진찰상 키 $171 \mathrm{~cm}$, 몸무게 $50 \mathrm{~kg}$ 으로 측정되었 고, 혈압, 맥박, 호흡수, 체온을 포함하는 활력징후와 혈중 산 소 포화도는 정상 범위 내에 있었다. 촉진시 경부와 흥부의 상부, 그리고 양측 어깨와 액와부까지 전반적인 부종 및 염 발음이 관찰되었다. 후두내시경 검사에서 구강 및 인후두에 
부종이나 염증, 그리고 점막손상 및 천공을 의심할 만한 소 견은 없었다. 흥부 방사선촬영에서 경부의 연조직과 상부 흥 벽의 피하기종 및 종격동 기종이 관찰되었고 기흥의 소견은 보이지 않았다(Fig. 1). 병변에 대한 정확한 평가를 위해 경 부 전산화단층촬영을 시행하였고, 경부와 흥벽 및 양측 어깨

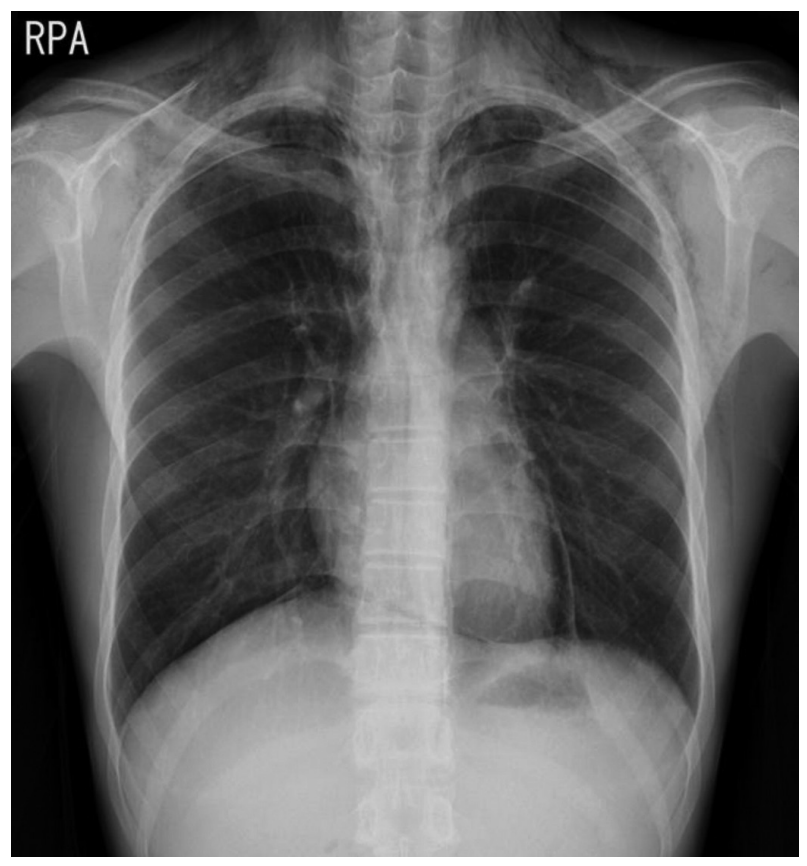

Fig. 1. Chest PA showing pneumomediastinum and subcutaneous emphysema of the neck, both shoulder and upper area of the chest.
와 액와부 연부조직의 피하기종뿐만 아니라 넓은 범위의 종 격동 기종과 척수의 경막외 기종 소견이 관찰되었다(Fig. 2). 혈액 검사에서는 백혈구 수치 및 $\mathrm{C}$ 반응 단백도 정상 범위 내 에 있었다.

자발성 종격동 기종과 이로 인해 발생한 경부 및 상부 흉 벽의 연부조직 피하기종과 척수 경막외 기종으로 진단을 내 리고 침상 안정과 치료적 금식 및 예방적 항생제 치료를 하였 다. 척수 경막외 기종에 대한 평가 및 치료를 위해 신경외과 협진을 시행하였다. 신경학적 검사에서 이상 소견은 관찰되 지 않았다. 자발성으로 발생한 경막외 기종에 대해서는 예방 적 항생제 치료 후 추적 관찰 전산화단층촬영을 계획하였다. 치료 시작 1 일 후부터 피하기종에 의한 부종과 염발음은 점 진적으로 완화되기 시작했고, 2 일째부터는 경구 식이를 시작 하였다. 3일이 지나면서 경부의 통증도 진통제가 필요 없을 만큼 호전되었고, 경부의 부종과 염발음도 호전되는 양상을 보여, 침상 안정을 유지하며 경과 관찰하였다. 입원 7일째 시 행한 흥부 방사선촬영과 척추 전산화단층촬영에서 척추의 골절이나 결손은 관찰되지 않았고, 척수 경막외 공간의 기종 은 거의 흡수되었으며, 신경학적 증상 또는 징후, 그리고 추 가적 합병증의 발생은 없어, 경부의 피하기종만 일부 남아 있 는 상태로 환자는 퇴원하였다(Fig. 3). 치료 시작 15일째 경 부 및 흥부에서 촉진되었던 피하기종과 염발음이 호전되었 고, 이후 3 개월째 추적 관찰 임상 소견 및 영상학적 검사상 재발의 소견은 보이지 않았다.
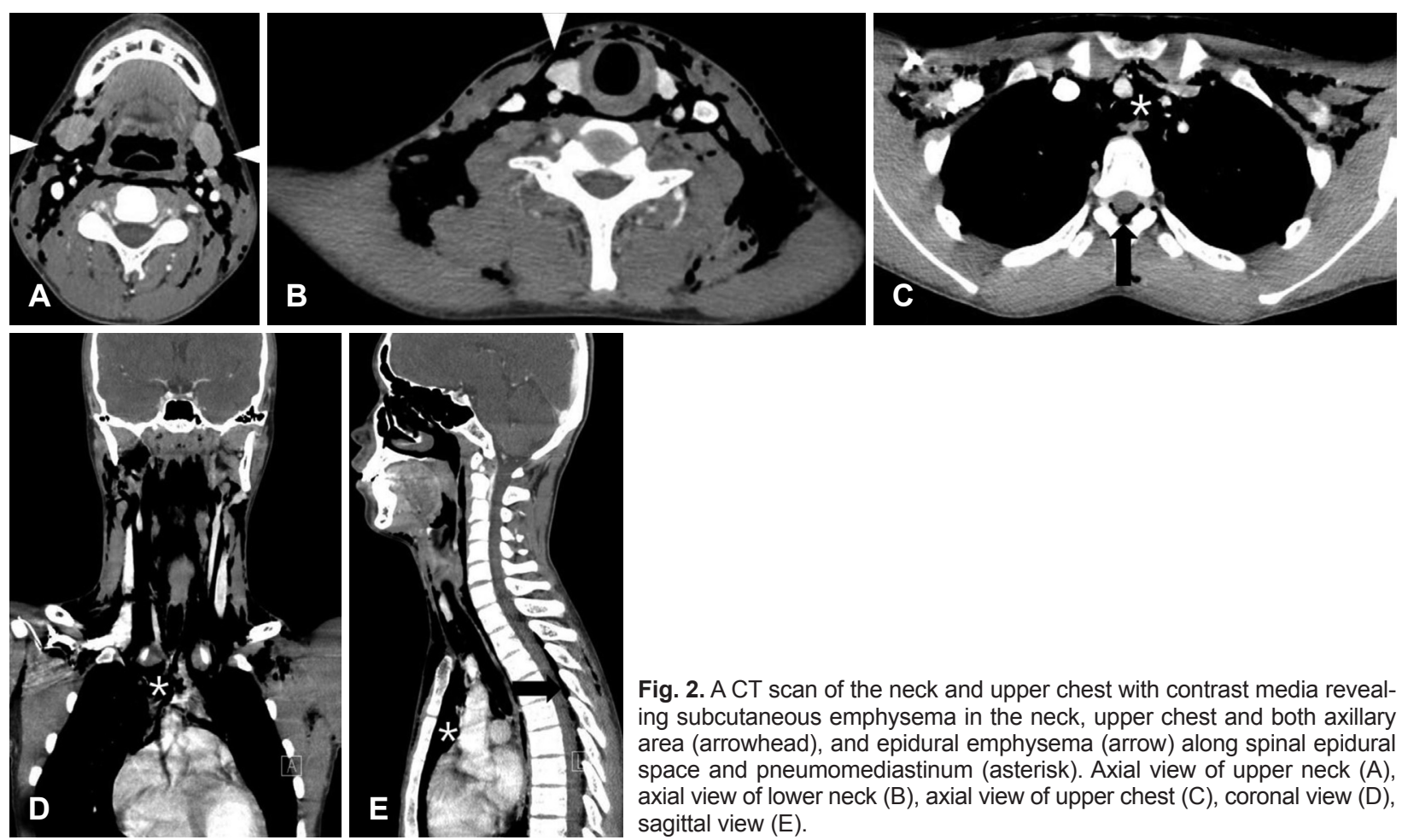

Fig. 2. A CT scan of the neck and upper chest with contrast media revealing subcutaneous emphysema in the neck, upper chest and both axillary area (arrowhead), and epidural emphysema (arrow) along spinal epidural space and pneumomediastinum (asterisk). Axial view of upper neck (A), axial view of lower neck (B), axial view of upper chest (C), coronal view (D), sagittal view $(E)$. 

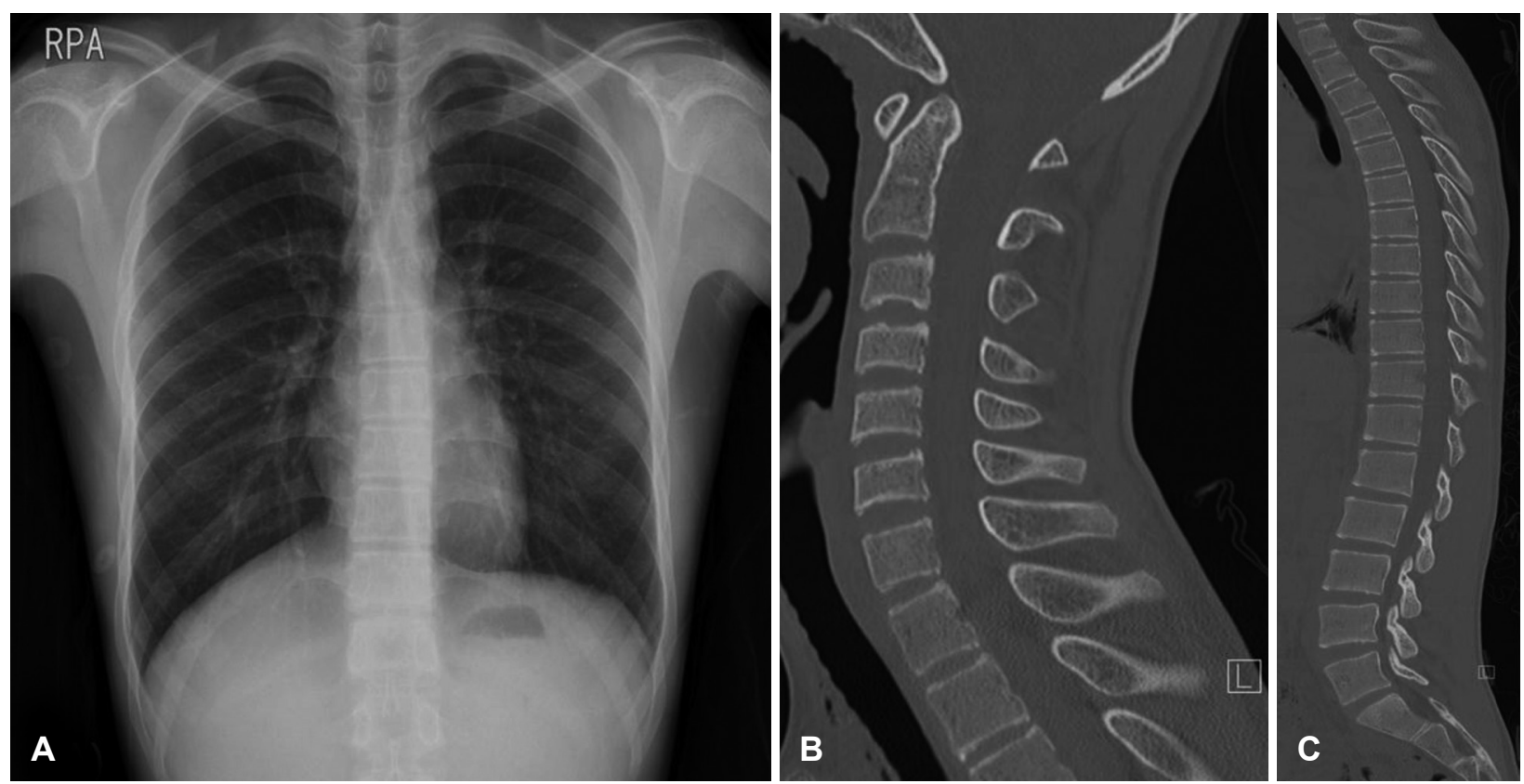

Fig. 3. Seven days after conservative treatment. Subcutaneous emphysema, pneumomediastinum and epidural emphysema resolved. Chest X-ray $(A)$, neck CT sagittal view $(B)$, spine CT sagittal view $(C)$.

\section{고 찰}

척수 경막외 공간에 공기가 존재하는 경막외 기종은 드물 게 발생하는 임상적 상황으로, 1977년 Gordon과 Hardman ${ }^{4)}$ 에 의해 두개골 외상으로부터 발생한 경막외 기종이 처음 보 고가 된 이후 전산화단층촬영의 발달과 보급으로 우연히 발 견되는 사례들이 증가하고 있다. 알려진 원인들로는 외상, 구 토, 자발성 기흥, 천식, 악성질환과 관련된 치료, 신경흥분제 복용, 마리화나 흡연, 요추 천자, 두개강내 수술 또는 척추 수 술 등이 있다. ${ }^{1)}$

경막외 공간은 foramen magnum을 경계로 뇌경질막과 척수경질막으로 나뉘어진다. 뇌경질막은 외측의 endosteal membrane과 내측의 meningeal membrane으로 구성되어 있고, foramen magnum에서부터는 meningeal membrane 만이 척수 뇌경질막을 구성하며 이어지기 때문에 이 두 공간 은 해부학적으로 분리가 되어 있다. ${ }^{5}$

척수 경막외 공간은 크게 다섯 가지 경로로 접근이 가능하 다. 첫 번째는 intervertebral vacuum disc의 파열에 의한 가 스 유출이다. 두 번째는 barotrauma(가슴 공기증, 종격동 기 종, 공기배증)에 의해 만들어진 기종이 신경공을 통해서 유입 될 수 있다. 세 번째는 요추천자, 경질막외 마취, 척추 뼈 골 절 또는 수술로 인해서 공기가 유입될 수 있다. 네 번째는 복 강내 감염에 의해 발생한 가스가 경막외 공간과 교통하고 있 는 pelvic vein에 의해 lumbar venous plexus로 유출 시 발 생할 수 있다. 다섯 번째는 두개골 골절에 의한 두개내 경질
막의 손상으로 두개내 척수강의 공기가 유입되는 경우이다.5)

지금까지 보고된 척수 경막외 기종과 관련된 증례에서는 폐 기종, 종격동 기종, 공기 머리증, 공기 심장막증, 경부 피하기종 중 하나 이상이 동반되어 있었다. ${ }^{1}$ 종격동 기종의 발생기전은 1939년 Macklin'에 의해 처음 보고되었으며 Macklin effect 로 알려져 있는데, 기침을 할 때 폐포와 간질 공간 사이의 압 력차가 증가함에 따라 폐포가 파열되고, 여기서 나온 공기가 기관지 폐포막을 통해 상대적으로 저항이 작은 종격동과 경부 의 근막을 따라서 진행하는 것이다. 소아에서 흔한 유발 원인 으로 천식, 구토, 발살바법, 과도한 신체운동이 보고되어 있 다.) 본 증례에서는 특별한 유발 요인 없이 자발성으로 종격동 기종이 발생한 것으로 판단이 된다. 종격동 후방에서 척수 경 막외 공간으로 공기가 유입되는 기전은 종격동 후방의 공기가 척추뼈 사이 구멍을 통해서 신경 얼기와 혈관들을 따라 일방 통행 밸브 메커니즘과 정맥신경 얼기를 통한 적접 전파의 두 가지 가설이 있다. ${ }^{2)}$ 그리고 척수 경막외 공간으로 유입된 공기 는 풍부한 혈관조직을 가지고 있는 전방의 척수 경막외 공간보 다는 상대적으로 느슨한 결합조직으로 인해 작은 저항을 가지 는 후방의 척수 경막외 공간에 공기가 모이는 경향이 있다. ${ }^{8)}$

본 증례의 환자에서는 과거력 및 현병력과 이학적 검사에 서 척수 경막외 기종, 종격동 기종, 경부 피하기종을 유발할 수 있다고 알려진 원인은 발견되지 않았다. 따라서 자발성 종 격동 기종이 발생하면서 후방 종격동의 공기가 해부학적으로 교통이 가능하며 상대적으로 저항이 작은 경부, 흥벽, 양측 어깨, 그리고 액와부 피하 연부조직과 척수 경막외 공간으로 
침범하면서 경부 피하기종과 척수 경막외 기종이 동반된 것 으로 추정된다. 이것은 처음 내원 당시, 그리고 퇴원 전 시행한 경부 및 흥부의 전산화단층촬영을 통해서 확인할 수 있었다.

자발성 종격동 기종의 치료는 합병증의 동반 여부에 따라 결정이 된다. 동반된 합병증이 없다면 통증 조절, 안정, 흥강 내의 압력을 높일 수 있는 행동을 자제하는 것과 같은 보존 적 치료만으로 충분하고 ${ }^{9}$ 재발률 또한 아주 낮기 때문에 환 자의 활동을 특별히 제한할 필요는 없다. ${ }^{10)}$ 척수 경막외 기종 은 발생 원인에 따라 다르지만, 보통은 일주일 내에 혈액내로 완전히 흡수되며 재발은 드문 것으로 알려져 있다. ${ }^{1)}$ 드물지 만 척수 경막외 공간으로 유입된 공기로 인하여 뇌수막염, 뇌 척수액 유출, 기뇌증이 발생할 수 있으며, 두개내 또는 척추 관내의 압력변화를 유발하여 감각이상, 운동신경 장애와 같 은 신경학적 증상이 발생했다는 보고도 있으므로 이에 대한 주의가 필요하다. ${ }^{11}$ 항생제의 사용에 대해서는 아직 명확한 치료 가이드라인이 없으며 그 효용성에 대해서는 논란의 여 지가 있는 상태이다. 뇌수막염의 증거만 없다면 예방적 항생 제의 사용은 필요 없다는 보고도 있으나, 지금까지 보고된 다수의 증례보고에서는 2 차 감염 예방 및 다른 합병증의 예 방을 위해 예방적 항생제를 사용하는 경향을 보였다. ${ }^{912-15)}$ 본 증례에서는 종격동과 피하기종뿐만 아니라 척수 경막외 공 간에까지 넓은 범위에 걸쳐서 기종이 발생하여 본원 신경외 과와 상의하에 항생제를 투여하였다.

자발성 종격동 기종, 피하기종과 함께 척수 경막외 기종이 진단된 경우 신경학적 후유증을 포함한 치명적인 합병증을 동반할 수 있으므로, 발생 원인에 대한 감별 진단이 중요하 며, 본 증례와 같이 유발 원인이 없고 동반된 합병증이 없는 경우 보존적 치료를 시행할 수 있다.

\section{REFERENCES}

1) Oertel MF, Korinth MC, Reinges MH, Krings T, Terbeck S, Gilsbach JM. Pathogenesis, diagnosis and management of pneumorrhachis.
Eur Spine J 2006;15 Suppl 5:636-43.

2) Chun BJ, Moon JM. Symptomatic epidural pneumorrhachis associated with an occult pneumomediastinum due to minor trauma. Spine (Phila Pa 1976) 2009;34(26):E979-82.

3) Germino JC, Medverd JR, Nguyen VT, Favinger JL, Marder CP. Craniocervical hyperpneumatization with concurrent pneumorrhachis, pneumomediastinum, and subcutaneous emphysema in a weightlifter. Spine J 2013;13(10):e47-53.

4) Gordon IJ, Hardman DR. The traumatic pneumomyelogram. A previously undescribed entity. Neuroradiology 1977;13(2):107-8.

5) Cloran F, Bui-Mansfield LT. Extracranial epidural emphysema: pathway, aetiology, diagnosis and management. Br J Radiol 2011;84 (1002):570-5.

6) Macklin CC. Transport of air along sheaths of pulmonic blood vessels from alveoli to mediastinum: clinical implications. Arch Intern Med 1939;64(5):913-26.

7) Chalumeau M, Le Clainche L, Sayeg N, Sannier N, Michel JL, Marianowski R, et al. Spontaneous pneumomediastinum in children. Pediatr Pulmonol 2001;31(1):67-75.

8) Bernaerts A, Verniest T, Vanhoenacker F, Van den Brande P, Petré C, De Schepper AM. Pneumomediastinum and epidural pneumatosis after inhalation of "Ectasy". Eur Radiol 2003;13(3):642-3.

9) Bilir O, Yavasi O, Ersunan G, Kayayurt K, Giakoup B. Pneumomediastinum associated with pneumopericardium and epidural pneumatosis. Case Rep Emerg Med 2014;2014:275490.

10) Sirotkin L, Ladde JG. A case of spontaneous pneumomediastinum and epidural pneumatosis in a young woman in the Emergency Department. J Emerg Med 2013;44(5):e353-5.

11) Harrod CC, Boykin RE, Kim YJ. Epidural pneumatosis of the cervicothoracic spine associated with transient upper motor neuron findings complicating Haemophilus influenzae pharyngitis, bronchitis, and mediastinitis. J Pediatr Orthop 2010;30(5):455-9.

12) Choo MJ, Kim YJ, Shin SO, Yong MG, Shin JW, Jeon CW. Nontraumatic subcutaneous emphysema in the head and neck. Korean J Otolaryngol-Head Neck Surg 2001;44(5):533-7.

13) Emiralioğlu N, Ozcan HN, Oğuz B, Yalçın E, Doğru D, Özçelik U, et al. Pneumomediastinum, pneumorrhachis and subcutaneous emphysema associated with viral infections: report of three cases. Pediatr Int 2015;57(5):1038-40.

14) Singh A, Kaur H, Singh G, Aggarwal S. Spontaneous pneumomediastinum with pneumopericardium, surgical emphysema, pneumothorax, and epidural pneumotosis: a rare association. J Nat Sci Biol Med 2014;5(1): 201-4.

15) Goh BK, Tan HK, Tan FL, Koong HN. Epidural emphysema associated with spontaneous pneumomediastinum. Am J Surg 2006;192(3):355-6. 